\title{
FORTY PERCENT OF 2 MILLION
}

\author{
PREPARING TO SERVE OUR VETERANS WITH \\ DISABILITIES
}

\section{Bruce C. Kelley, Ernetta L. Fox, Justin M. Smith, Lisa A. Wittenhagen, University of South Dakota}

On August 1, 2009, the Post-9/11 Veterans Educational Assistance Act of 2008 was passed, and as a result, almost 2 million veterans returning from Iraq and Afghanistan will soon enroll in postsecondary education. Up to 40 percent of these veterans are estimated to have disabilities. This chapter examines some of the characteristics of this group, the challenges that veterans face as they transition into life as college students, and how faculty developers can belp faculty better serve these incoming veterans.

John (named changed to protect identity) is medically retired from the Air Force, having served in both Operation Enduring Freedom (OEF) and Operation Iraqi Freedom (OIF). He has major depression and social phobia. Despite these challenges, he has decided to get a bachelor's degree in alcohol and drug studies:

I do pretty well but the depression hits me every so often and it makes it difficult for me to study. I'm also so highly medicated at times that I can't really function. I may spend most of the week in bed and my attention and focus aren't that well. I was a 3.8 grade point average student but because of my depression I've fallen to a 2.5 grade point average. I've gotten a couple of F's since I fell

The material in this chapter was developed under a congressionally directed grant administered through the U.S. Department of Education. However, it does not necessarily represent the policy of the Department of Education and does not assume endorsement by the federal government. 
so far behind that I couldn't catch up. I've also failed most of my correspondence courses since I really lack the motivation and since I don't have deadlines I put everything off and just focus on my online classes so I don't fall behind. I really struggle between the depression, or maybe I'm just not motivated. I know with having social phobia I'll never use my degree but it's a goal in life and it gives me something to keep me going. . . . I've never used the disability services. I've always felt like I wouldn't qualify.

John's story is far from unique. As of the 2007-2008 academic year, military veterans, active-duty service members, and reserves (referred to throughout the rest of this chapter as student veterans) constituted 4.2 percent of the total undergraduate population in the United States-875,000 students enrolled nationwide (Radford \& Wun, 2009). The Post-9/11 Veterans Educational Assistance Act of 2008 (post-9/11 GI bill) was passed on August 1,2009, and as a result, almost 2 million veterans returning from the Iraq and Afghanistan wars will soon enroll in postsecondary education (American Council on Education, 2008). Veterans returning from OEF and OIF are different from those of past generations. Advances in body armor, vehicle protection, medical procedures, and treatment mean that up to 40 percent of these veterans will be enrolling in college with both visible and invisible disabilities (Grossman, 2009). Forty percent of 2 million: Are we, as faculty developers, ready to help our faculty serve these incoming student veterans? What do faculty need to know about this incoming surge of students who will have such unique challenges?

\section{Characteristics of Veterans Returning to Higher Education}

Veterans returning to school under the post-9/11 GI bill are demographically different from the typical incoming first-year student. Of all military undergraduates in the classroom, 84.5 percent are older than the traditional college student, 47.3 percent are married, and 47.0 percent of them have children, including $\mathbf{1 4 . 5}$ percent who are single parents (Radford \& Wun, 2009). As a group, military members and veterans seek associate degree programs at two-year colleges at a higher rate than the traditional college population. An astounding 76.6 percent of them do not attend school full time for an entire academic year, and only 37.7 percent of military undergraduates used veterans' education benefits during the 2007-2008 academic year, although the post-9/11 GI Bill may change this dramatically (Radford \& Wun, 2009). 


\section{Veterans and Disabilities}

Veterans returning to higher education are doing so with a variety of physical and psychological disabilities. Bilmes (2008) estimates that

more than 70,000 have been wounded in combat, injured in accidents, or airlifted out of the region for emergency medical care. More than a third of the 750,000 troops discharged from the military so far have required treatment at medical facilities, including at least 100,000 with mental health conditions and 52,000 with posttraumatic stress disorder [PTSD]. According to a recent U.S. Army estimate, as many as 20 percent of returning soldiers have suffered mild brain injuries, such as concussions. More than 20,000 troops have survived amputations, severe burns, or head, spinal, and other serious injuries. (p. 84)

Veterans may also return to higher education with hearing disorders (Lew et al., 2007) and eye injuries (Thatch et al., 2008). Warden (2006) found that 28 percent of all individuals medically evacuated to the Walter Reed Army Medical Center had traumatic brain injury (TBI), and Kennedy et al. (2007) found that between January 2003 and February 2007, 29 percent of the patients medically evacuated to Walter Reed Army Medical Center had evidence of both TBI and PTSD. Hoge, Auchterlonie, and Milliken (2006) reported that

the prevalence of reporting a mental health problem was $19.1 \%$ among service members returning from Iraq compared with $11.3 \%$ after returning from Afghanistan and $8.5 \%$ after returning from other locations.... Thirty-five percent of Iraq war veterans accessed mental health services in the year after returning home; $12 \%$ per year were diagnosed with a mental health problem. (p. 1023)

Many of the soldiers who need treatment often do not even report mental health problems or seek help due to the stigma of seeking psychiatric assistance, especially in a volunteer army where many are seeking to advance their careers (Hoge et al., 2004; Litz \& Orsillo, 2004).

TBI and PTSD deserve special mention, for they are in some respects invisible. Students suffering from TBI or PTSD are not as clearly identifiable to a faculty member as someone with, say, an amputation. TBI produces a number of symptoms, many of them similar to common types of learning disabilities According to Okie (2005), "Cognitive changes .. . may include disturbances in attention, memory, or language, as well as delayed reaction time during problem-solving. Often, the most troubling 
symptoms are behavioral ones: mood changes, depression, anxiety, impulsiveness, emotional outbursts, or inappropriate laughter" (pp. 2045-2046). PTSD can affect students in a variety of ways. It can inhibit interaction with peers during discussion and group work because students with PTSD are often reluctant to share their thoughts and opinions, and some course topics might cause extreme anxiety for them. It can cause a student discomfort in classes where seating is not the same from week to week or in classes that are exceptionally large, and it has an impact on the student's ability to focus in a timed setting when there are distractions in the room such as shuffling noises or people in the hallway. The disorder can also cause difficulty in concentrating and reading for extended periods of time and has been linked to substance abuse, acute stress disorder, somatoform disorders, depression, and other mood and anxiety disorders (Cozza et al., 2004). One of the most difficult challenges of PTSD is that it sometimes has a delayed onset (Hoge et al., 2008), and symptoms of the disorder can begin to manifest themselves after the student has transitioned into higher education.

Large numbers of veterans are returning from OIF and OEF with varying types and degrees of disabilities. It is to the benefit of both these veterans and higher education to create supportive environments for these men and women if we wish to fulfill the promise this country makes to educate its veterans. As Duane (2007) succinctly states, "Those who have sacrificed so much for our country deserve physical and mental health care, educational opportunities, and a real chance to live fulfilling lives" (p. 2123).

\section{Transitions}

The transition of a veteran from the military into higher education produces a unique set of experiences, challenges, and stresses. Some of these are positive; the experience of serving can provide "greater self-efficacy, enhanced identity and sense of purposefulness, pride, camaraderie, etc." (Litz \& Orsillo, 2004, p. 21). The experience can also have negative impacts on life, work, and learning in both the short and long terms. Some of the challenges veterans face as they transition to higher education can include (University of Michigan-Flint, 2010):

- Insomnia

- Difficulty concentrating

- Recurring thoughts and memories of war experiences 
- Hyperalertness (difficulty relaxing or feeling safe even in an unthreatening environment) and startle reactions

- Grief and sadness over losses

- Guilt (surviving when others died)

- Anger

- Impatience and low tolerance for frustrations (civilian rules may seem irrelevant or meaningless)

- Difficulty connecting with and trusting others, especially those without war zone experience

- Anxiety about being redeployed

Student veterans must learn to develop an identity that goes beyond that of the military, and as they merge into the nonveteran student population, they must deal with a variety of issues-for example (University of Michigan-Flint, 2010):

- Difficulty relating to and connecting with traditional college students

- Difficulty finding importance and meaning in experiences and ideas that are not life or death

- Difficulty negotiating the structural and procedural differences between the military and higher education bureaucracies

- Making a greater number of decisions in a far more complex world (the number of independent decisions that must be madewhen to get up, where to eat, and what to do that day-are far more limited in the military than for traditional college students)

- Developing a sense of safety on campus (sitting in areas of the classroom that give them a clear view of who is going in and out of the door)

- Struggling with boredom (few classes compare with a firefight in terms of excitement)

Student veterans with disabilities discover that even language about disability changes as one navigates through the military, the Veterans Administration (VA), and the Americans with Disabilities Act (ADA). The military defines a disability as a service-connected physical or mental impairment that renders a member unfit to perform his or her required duties, while the VA defines disability as a mental or physical disease or injury resulting from or aggravated by military service. Broadly speaking, 
the amended ADA defines disability as a physical or mental impairment, a history or record of such an impairment, or being regarded by others as having an impairment (Miller \& Smith, 2011). The subtle differences in these definitions mean that student veterans are sometimes considered able by one agency and disabled by another. The ADA tends to be broader in scope, and service members who receive only a partial disability under VA regulations may be entitled to full accommodations in higher education. The result of this complex situation is that students should not base their eligibility for academic accommodations on their disabilities classification through the military or the VA.

There has been a growing awareness that higher education needs to be better prepared to serve student veterans. Some notable initiatives include the Minnesota State College and University system's My Military Education Program, the University of Arizona's Supportive Education for Returning Veterans Program, Cleveland State University's Veteran Student Success Program, Montgomery College's Combat2College Program, and George Washington University's Yellow Ribbon Program. In general, however, there has been little emphasis on preparing faculty, staff, and administration to serve veterans with disabilities. Momentum for providing on-campus support for, and increased retention of, these veterans currently lags efforts to get them on campus in the first place.

\section{Preparing Faculty to Better Serve Veterans}

It is important for faculty to recognize the transitional challenges that student veterans must overcome as they move to higher education. We have identified three broad, and at times overlapping, areas where faculty developers can suggest specific strategies to enable faculty to better serve veterans with disabilities: course structure and design, learning activities, and classroom environment. The strategies, which we describe next, will improve the chances for academic achievement for all students, but they are especially important in enabling student veterans with disabilities to succeed in higher education. Keep in mind that every veteran is unique, and that the generalizations we describe will not apply to all student veterans or even to every student veteran with a disability.

\section{Course Structure and Design}

Structural elements that faculty should be aware of fall along a continuum that ranges from specific design elements for individual courses at one end to university-wide instructional policies regarding the disability 
accommodations at the other. The structure of individual courses should be reevaluated in light of the unique challenges student veterans face and redesigned where appropriate. Faculty generally do not need to know the intimate details of VA medical processes, for example, but they should be informed that the system is not at all like scheduling an appointment with a family physician. VA appointments, if cancelled, often cannot be rescheduled until months later. Faculty should develop attendance and class participation policies that do not penalize student veterans who have to miss class because of VA appointments. Military obligations, such as weekend training for National Guard units, should be regarded as the same type of excused absence that faculty would extend to sports-related absences. Assignments should all be clearly defined in the syllabus, for student veterans have been trained to communicate in a clear, direct manner and to work toward specific goals. Rubrics and assignment templates that are included with the basic course materials can help provide that clarity. Consider scaffolding longer assignments, such as term papers, as a series of several smaller tasks with specific deadlines. Many students, including student veterans, struggle with structuring their time to finish larger academic tasks.

Emphasizing the reflective quality of academic work is important as well. The military trains its members to make rapid decisions, and "student veterans with disabilities will benefit from experiences that help them in learning that rarely will they need to make such harrowing split second decisions and that when a decision needs to be made, they should spend the necessary time to do so" (Branker, 2009, p. 62). Student veterans will benefit from a course structure that encourages them to take their time with assignments and to be deliberately thoughtful in their academic activities. Asynchronous communication, through the use of learning management discussion boards, wikis, blogs, or tweets, can help student veterans build in time for this reflection (Grabinger, 2010).

At a larger structural level, instructors should be aware of institutional policies regarding students with disabilities. Faculty developers should develop a working relationship with their institution's office of disabilities services (ODS) and should encourage their faculty to do so as well. Faculty should know how the process of granting accommodation works at their institution and should be given basic information about the most common disabilities that veterans experience. This is especially true of TBI and PTSD, for they can manifest themselves in ways that often appear to be common learning disabilities and may have a delayed onset. A student veteran who did not have a learning disability prior to deployment may not understand why he or she is now having trouble concentrating or 
memorizing and may be resistant to using disability services. Students who grow up with learning disabilities often discover them in elementary school, and by the time they have reached college, they have had a number of years to master the language of accommodation and understand their rights and their responsibilities. Student veterans with disabilities are unlikely to have this familiarity and may need to be encouraged to seek information from the ODS. At the very least, every faculty member should include a statement on the syllabus regarding the ADA. Finally, the principles of universal design can provide faculty with numerous ways to better serve all students with disabilities, including those who are student veterans. These principles include making course materials available in a variety of formats, providing a fully accessible physical environment, and assessing students through a variety of measures. Burgstahler and Cory (2008) provide the definitive exploration of universal design in higher education.

\section{Learning Activities}

Numerous specific teaching strategies and styles can have a positive impact on the learning experience of student veterans with disabilities. Because they are typically older, many student veterans are interested in practical and hands-on types of activities, such as service-learning projects, case studies, simulations, and field research. Team projects, if they are clearly defined and have unambiguous goals, can enhance the educational experience of student veterans, for they have been trained to work as a team to accomplish specific missions. Branker (2009) recommends that "an intentionally designed educational environment for student veterans with disabilities should emphasize collaboration, not competition and isolation" (p. 62). Assignments that foster teamwork are one way to provide this environment.

Student veterans may also struggle with the difference in communication styles between the military and the typical college classroom. The military teaches a brief and direct communication style. Faculty therefore may need to spend extra time with student veterans, mentoring them on how to communicate in a voice that is more appropriate for an academic setting. Activities that encourage students to argue ideas or explore issues from different viewpoints can help veterans learn a more academic communication style.

One of the foundational principles of universal design is to let students demonstrate knowledge in multiple ways. Faculty should consider constructing a wide variety of assignments within each course, such as 
weekly question cards, study guides, self-assessments, attendance at campus events, participation in community service projects, writing assignments, oral presentations, small-group multimedia projects, and exams (Higbee, 2008). A wide variety of assignments ensures that students who struggle with specific methods of assessment (for example, test taking or in-class writing assignments) will have other options to show mastery of course materials and activities. An array of assessment strategies benefits all students, but is especially important for students with disabilities, such as a student veteran who has recently lost his or her primary writing hand.

Activities that make use of educational technology can provide numerous benefits to student veterans with disabilities. Multiple versions of course content can be created through the use of streaming video (especially if close-captioned), podcasts, narrated slides, and course-related websites. Students in turn can create content through a variety of media. Social media and online collaborative writing tools can provide an engaging learning experience for all students, including student veterans with disabilities.

\section{Classroom Environment}

Faculty should be aware that the success of student veterans is often tied to the physical and emotional environment of the classroom. Student veterans who have recently returned from conflict often feel insecure in large classrooms or in classrooms with multiple doors. They have been trained to secure rooms, meaning that everything is searched and all exits closed or watched. The general hubbub and commotion of 150 students (with their unsearched backpacks) interacting in a room can be intimidating or distracting for student veterans, especially those with neurological disorders. Some student veterans want to sit in a location (such as the back row of the room) where they can easily watch everyone and where their "back" is secure. For that reason, rooms with lots of windows or glass walls or that are generally open can be distracting. Faculty may need to work with their ODS to find ways of best serving student veterans who are struggling with the physical classroom environment. Student veterans often find the behavior of their fellow students disruptive. Whispering, texting, or Web surfing (in ways unrelated to course content) are foreign to the typical military briefing and can be highly distracting for student veterans.

The emotional environment of the class is also an essential element in the success of student veterans. While faculty should foster an atmosphere 
that encourages direct communication with all their students, this is especially important with veterans. First-year noncombat veterans reported that they were less engaged with faculty than their peers were, and combat and noncombat veterans who were academic seniors reported significantly lower student-faculty interaction and less support from their campus environment than did nonveteran students (National Survey of Student Engagement, 2010). In light of these results, faculty should make concentrated efforts to interact with their student veteran population both in and outside the classroom. Many student veterans are quietly proud of their military service and are uncomfortable with overt displays of recognition (positive or negative) that single them out from their classmates. Faculty may wish to devise nonintrusive ways of identifying these students-perhaps by collecting information from all students on note cards or through an online survey. Student veterans have experienced the world in many ways that most other students have not, and developing assignments and activities that draw on this experience will provide a supportive environment that enriches the entire class.

Faculty should thoughtfully consider how they handle in-class issues related to the global war on terror in general and the Middle East in particular. Within the veterans' community itself, there are many opinions about our current wars, from unwavering support to unswerving criticism. As a result, faculty should find ways of discussing current events and Middle Eastern policies in a way that distinguishes political policies and military strategies from individuals who have had to carry out those policies. Finally, faculty need to understand that certain questions should never be asked of a student veteran, including, "Did you kill anyone?" "Did you see anyone die?" and other intrusively personal questions. Advise faculty to avoid asking these questions in class, and if students ask them, they should step in immediately to redirect the question, as they would with any patently offensive statement made in that environment.

\section{Conclusion}

There is a great need for faculty, staff, and administration to better understand the challenges that veterans returning from OEF and OIF face, and faculty developers need to be prepared to help faculty better serve those veterans who are entering higher education with disabilities. As Cook and $\mathrm{Kim}(2009)$ state, "Veterans are not necessarily looking to be isolated or have special programs created on their behalf. More than anything, they are looking for an educational environment that provides the tools and resources that allow them to succeed" (p. 29). When we 
provide student veterans with disabilities with the opportunity for an extraordinary education, we also add immeasurably to the educational experiences of the entire academic community.

Terry (named changed to protect identity) is a service-connected veteran with a disability. This is his story, in his own words:

No two experiences veterans have are the same, but we share many things in common when returning to school. In my case the ED[ucation] graduate program I started in 2001 was interrupted for two years for OEF/OIF from 2003-2005. When I returned home to South Dakota I no longer had the finances to complete the program as I had two of my own children in college. Four long years later a G.I. Bill for Reservists was passed and in 2009 I resumed taking classes to complete the program I had started in 2001. The School of Education faculty had changed, and my advisor and entire committee had either retired or left in those intervening years. I applied/appealed for an extension to complete my program. My situation is not unique and only because of an understanding School of Ed Department head and tenacity and commitment on my part was I able to [continue my program].

With the proper support, our veterans with disabilities can thrive. As of this writing, Terry is only four weeks away from graduation, a success story that makes us all proud.

\section{REFERENCES}

American Council on Education. (2008). Serving those who serve: Higher education and America's veterans. Retrieved from www.acenet.edu/Content/ NavigationMenu/ProgramsServices/MilitaryPrograms/serving/index.htm Bilmes, L. J. (2008). Iraq's 100-year mortgage. Foreign Policy, 165, 84-85. Branker, C. (2009). Deserving design: The new generation of student veterans. Journal of Postsecondary Education and Disability, 22(1), 59-66.

Burgstahler, S. E., \& Cory, R. C. (Eds.). (2008). Universal design in higher education: From principles to practice. Cambridge, MA: Harvard Education Press.

Cook, B. J., \& Kim, Y. (2009). From soldier to student: Easing the transition of service members on campus. Washington, DC: American Council on Education.

Cozza, S. J., Benedek, D. M., Bradley, J. C., Grieger, T. A., Nam, T. S., \& Waldrep, D. A. (2004). Topics specific to the psychiatric treatment of military personnel. In Iraq war clinician guide (2nd ed., pp. 4-20). 
Washington, DC: U.S. Department of Veterans Affairs, National Center for PTSD. Retrieved from www.ptsd.va.gov/professional/manuals/iraqwar-clinician-guide.asp

Duane, J. F. (2007). True patriotism. American Journal of Public Health, 97(12), 21-23. doi:10.2105/AJPH.2007.125237

Grabinger, S. (2010). A framework for supporting postsecondary learners with psychiatric disabilities in online environments. Electronic Journal of e-Learning, 8(2), 101-110.

Grossman, P. D. (2009). Forward with a challenge: Leading our campuses away from the perfect storm. Journal of Postsecondary Education and Disability, 22(1), 4-9.

Higbee, J. L. (2008). The faculty perspective: Implementation of universal design in a first-year classroom. In S. E. Burgstahler \& R. C. Cory (Eds.), Universal design in higher education: From principles to practice (pp. 61-72). Cambridge, MA: Harvard Education Press.

Hoge, C. W., Auchterlonie, J. L., \& Milliken, C. S. (2006). Mental health problems, use of mental health services, and attrition from military service after returning from deployment to Iraq or Afghanistan. Journal of the American Medical Association, 295(9), 1023-1032.

Hoge, C. W., Castro, C. A., Messer, S. C., McGurk, D., Cotting, D. I., \& Koffman, R. (2004). Combat duty in Iraq and Afghanistan, mental health problems, and barriers to care. New England Joumal of Medicine, 351(1), 13-22.

Hoge, C. W., McGurk, D., Thomas, J. L., Cox, A. L., Engel, C. C., \& Castro, C. A. (2008). Mild traumatic brain injury in U.S. soldiers returning from Iraq. New England Journal of Medicine, 358(5), 453-463.

Kennedy, J. E., Jaffee, M. S., Leskin, G. A., Stokes, J. W., Leal, F. O., \& Fitzpatrick, P. J. (2007). Posttraumatic stress disorder and posttraumatic stress disorder-like symptoms and mild traumatic brain injury. Journal of Rebabilitation Research and Development, 44(7), 895-920. doi:10.1682/ JRRD.2006.12.0166

Lew, H. L., Jerger, J. F., Guillory, S. B., \& Henry, J. A. (2007). Auditory dysfunction in traumatic brain injury. Journal of Rehabilitation Research and Development, 44(7), 921-928. doi:10.1682/JRRD.2007.09.0140

Litz, B., \& Orsillo, S. M. (2004). The returning veteran of the Iraq war: Background issues and assessment guidelines. In Iraq war clinician guide (2nd ed., pp. 21-32). Washington, DC: U.S. Department of Veterans Affairs, National Center for PTSD. Retrieved from www.ptsd.va.gov/ professional/manuals/iraq-war-clinician-guide.asp

Miller, W. K., \& Smith, J. (2011, January). Student veterans with disabilities:

Transition to bigher education. Paper presented at the Fides: Developing the Academic Promise for Our Student Veterans Workshop, Vermillion, SD. 
National Survey of Student Engagement. (2010). Major differences: Examining student engagement by field of study-Annual results 2010. Bloomington: Indiana University, Center for Postsecondary Research.

Okie, S. (2005). Traumatic brain injury in the war zone. New England Journal of Medicine, 352(20), 2043-2047.

Radford, A. W., \& Wun, J. (2009). Issue tables: A profile of military service members and veterans enrolled in postsecondary education in 2007-08. Retrieved from http://nces.ed.gov/pubs2009/2009182.pdf

Thatch, A. B., Johnson, A. J., Carroll, R. B., Huchun, A., Ainbinder, D. J., Stutzman, R. D., Blaydon, S. M., . . Fannin, L. A. (2008). Severe eye injuries in the war in Iraq, 2003-2005. Ophthalmology, 115(2), 377-382.

University of Michigan-Flint. (2010). For the returning war veteran. Retrieved from http://beta-www.umflint.edu/studentveterans/for_the_returning_war_ veteran.htm

Warden, D. (2006). Military TBI during the Iraq and Afghanistan wars. Journal of Head Trauma Rehabilitation, 21(5), 398-402. 